- text. It would also investigate why HIV/AIDS was heterosexually transmitted in southern Africa, and assess drug-based responses, including strategies to prevent mother-tochild transmission, she said.

Panel members include the French discoverer of the AIDS virus, Luc Montagnier, and Clifford Lane of the US National Institutes of Health. Twelve of the panel are USbased, and ten are African, including seven South Africans and representatives from Uganda, Malawi and Senegal. There are also members from Cuba, Mexico and India.

Significantly, with the exception of Sam Mhlongo of the Medical University of South Africa, none of the African representatives belong to the dissident camp. But several prominent South African AIDS researchers, all of whom have been outspokenly critical of the dissident movement, were not included. These include Jerry Coovadia of Natal University (convenor of the World AIDS Congress to be held in Durban in July), James McIntyre of the University of the Witwatersrand, immunologist Johnny Sachs, Gary Maartens of the University of Cape Town, and epidemiologist Bryan Williams of the Council for Scientific and Industrial Research.

"Although it's very important to determine innovative strategies for combating AIDS, engaging with fringe groups is not the way forward," says Glenda Gray, director of

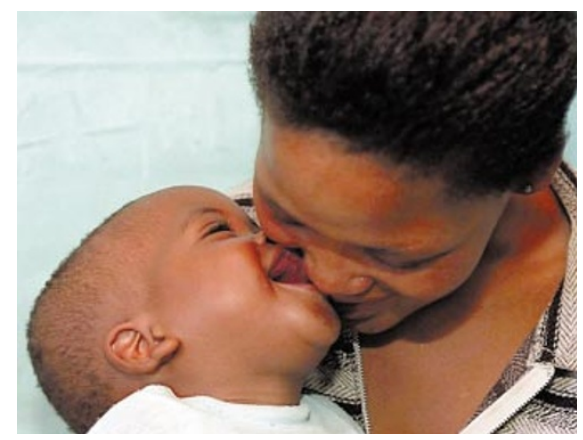

Parents and their children could be HIV-tested.

the perinatal HIV research unit at Johannesburg's Baragwanath hospital, who was also excluded from the panel. "These people should never have been given a platform."

Although Tshabalala-Msimang described the meeting as a "wonderful experience", it is said to have been very acrimonious, with the dissidents finding themselves in a minority in each of three groups appointed to discuss the causes, prevention and treatment of AIDS.

Instead of a final round-table discussion, the meeting is understood to have divided into groups representing the orthodox and dissident views.

The panel's chief facilitator, lawyer Stephen Owen of the Institute for Dispute Resolution at the University of Victoria in Canada, said at the press conference follow- ing the meeting that reaching consensus had not been the objective. "Divergent points of view remain, in very stark terms," he said.

The panel will enter into a "closed Internet debate" over the next four to six weeks, before reconvening in South Africa for a four-day discussion before the start of the World AIDS Congress on 9 July.

The task force is widely interpreted as a face-saving device for Mbeki, who admitted at the meeting's opening that he was "embarrassed to say" that he had "discovered that there had been a controversy about this for some time". Quoting the Irish poet Patrick Henry Pearse, Mbeki pondered whether his having raised the issue was "folly or grace".

There has been some speculation that a last-minute deal to add three extra nondissident members to the panel - thereby creating an overall majority of non-dissidents - was brokered at a high level between the South African and US governments.

The three additional names had not appeared on the initial list announced last week; neither Tshabalala-Msimang nor Essop Pahad, cabinet minister in the President's office, were prepared to confirm this at the press conference.

Some South African AIDS researchers feel that if the proposed surveys counter the claims of the dissident movement, they will have done a useful service.

\title{
French research minister targets IT and biotech
}

\section{Paris}

France's new research minister, Roger-

Gérard Schwartzenberg, promised last week that the government will substantially increase its support for research in information technology and biotechnology.

Schwartzenberg says that over four years he will double the research budget of France's computing research agency, INRIA, which received FF408 million (US\$56 million) in state support in 1998. In addition, a computer science division will be created at the Centre National de la Recherche Scientifique.

Schwartzenberg plans to use the research ministry's own funds to pay for these increases. He says that the money allocated for new technologies from the National Science Funds and the Funds for Technology Research, which the ministry directs, will increase by 50 per cent next year.

The budget increases were announced by Schwartzenberg during his first public speech on his plans for the post. He was appointed to head the research ministry in March after his predecessor, Claude Allègre, was sacked by the prime minister, Lionel Jospin, in a cabinet reshuffle.

Unlike Allègre, who ran a superministry overseeing higher education and research, Schwartzenberg will "have all of his time to dedicate to raising the research budget", says Vincent Courtillot, who served as research director under Allègre and will retain a similar position in the new ministry.

One priority highlighted by Schwartzenberg last week is to boost spending for life-sciences research. He also plans to set aside FF200 million as seed money for biotechnology companies, as well as a national network of 'incubators' specialized in raising biotech start-ups.

On most fronts, Schwartzenberg will continue with the policies of his predecessor. But he has broken with Allègre's opposition to building a new synchrotron facility on French soil (see Nature 404, 533; 2000). The new minister, while continuing a partnership with the British government and the Wellcome Trust to build the synchrotron Diamond in Britain at the Rutherford Appleton Laboratory near Oxford, is also pursuing a third-generation machine in France.

Last week Schwartzenberg met with British science minister Lord Sainsbury and discussed the possibility of British cooperation in the French project, Soleil. A

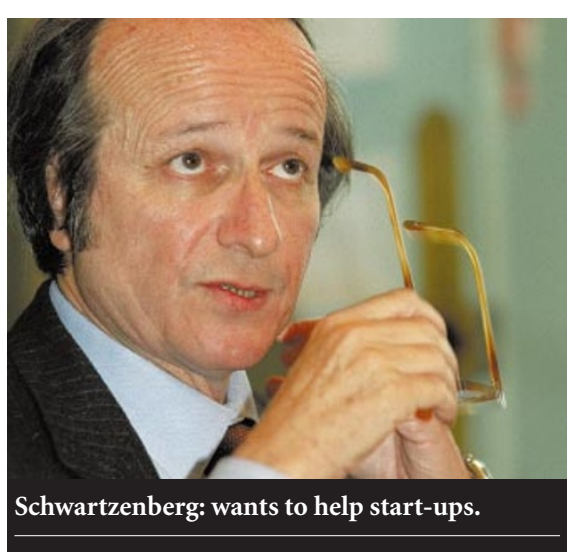

statement issued after the meeting said that the two facilities "would enable the scientific community in the future to cover a wide range of applications of synchrotron radiation".

Schwartzenberg's appointment coincides with France assuming the presidency of the European Union in July. In last week's presentation, he said he favoured accelerating the creation of a European patent, creating incubators and seed money for new technology companies, and harmonizing the tax system to favour the creation of new companies. Heather McCabe 